\title{
Efficacy and safety of tocilizumab in the management of COVID- 19: A systematic review and meta-analysis of observational studies
}

\author{
Gollapalle L Viswanatha ${ }^{1 *}$, CH K V L S N Anjana Male ${ }^{2}$, Hanumanthappa Shylaja ${ }^{3}$ \\ ${ }^{1}$ Independent Researcher and Consultant, Kengeri, Bangalore -560060, Karnataka \\ ${ }^{2}$ Department of Pharmaceutical Chemistry and Phytochemistry, Nirmala College of Pharmacy, \\ Mangalagiri -522503, Andhra Pradesh \\ ${ }^{3}$ Independent Researcher, Kengeri, Bangalore -560060, Karnataka
}

\section{*Corresponding Author}

\section{Dr.G.L.Viswanatha}

No.387/511/A, Megalabeedi, Kengeri

Bangalore-560 060

Karnataka, India

Email:glv_000@yahoo.com

Mob: +91-9844492334

Phone no.: +91-80-28482862

Fax:+91-80-28482862 


\title{
Efficacy and safety of tocilizumab in the management of COVID-19: A systematic review and meta-analysis of observational studies
}

\begin{abstract}
Background: This systematic review and meta-analysis was aimed to evaluate the efficacy and safety of tocilizumab (TCZ) in treating severe coronavirus disease 2019 (COVID-19).

Methods: The electronic search was performed using PubMed, Scopus, CENTRAL, and Google scholar to identify the retrospective observational reports. The studies published from 01 January 2020 to 30th September 2020. Participants were hospitalized COVID-19 patients. Interventions included tocilizumab versus placebo/standard of care. The comparison will be between TCZ versus standard of care (SOC)/placebo. Inconsistency between the studies was evaluated with $I^{2}$ and quality of the evidences were evaluated by Newcastle-Ottawa scale.
\end{abstract}

Results: Based on the inclusion criteria there were 24 retrospective studies involving 5686 subjects were included. The outcomes of the meta-analysis have revealed that the TCZ has reduced the mortality (M-H,RE-OR $-0.11(-0.18$ to -0.04$\left.) 95 \% \mathrm{CI}, \mathrm{p}=0.001, I^{2}=88 \%\right)$ and increased the incidences of super-infections (M-H, RE-OR 1.49(1.13 to 1.96$) 95 \% \mathrm{CI}, \mathrm{p}=0.004$, $\left.I^{2}=47 \%\right)$. However, there is no significant difference in ICU admissions rate (M-H, RE-OR $0.06(-0.23$ to 0.12$\left.), I^{2}=93 \%\right)$, need of MV (M-H, RE-OR of $0.00(-0.06$ to 0.07$\left.), I=74 \%\right)$, LOS (IV $-2.86(-0.91$ to 3.38$\left.), I^{2}=100 \%\right)$, LOS-ICU (IV: $-3.93(-12.35$ to 4.48$), I^{2}=100 \%$ ), and incidences of pulmonary thrombosis (M-H, RE-OR $1.01(0.45$ to 2.26$\left.), I^{2}=0 \%\right)$ compared to SOC/control.

Conclusion: Based on cumulative low to moderate certainty evidence shows that TCZ could reduce the risk of mortality in hospitalized patients. However, there is no statistically significant difference observed between the TCZ and SOC/control groups in other parameters. 
medRxiv preprint doi: https://doi.org/10.1101/2021.01.27.21250599; this version posted February 23, 2021. The copyright holder for this preprint (which was not certified by peer review) is the author/funder, who has granted medRxiv a license to display the preprint in perpetuity.

All rights reserved. No reuse allowed without permission.

Keywords: COVID 19; tocilizumab, cytokine storm, interleukin-6, retrospective studies.

\section{Introduction}

Coronavirus diseases (COVID-19) is a viral disease caused by severe acute respiratory syndrome corona virus-2(SARS-CoV-2) that originated from Wuhan city of Hubei province in China in December 2019[1]. Globally it has caused a significant burden on public health through a drastic increase in the morbidity and mortality rate[2]. The available evidence suggests that most of the infected patients will remain asymptomatic or develop mild symptoms, however nearly $20 \%$ of the infected individuals would develop severe pneumonia and respiratory distress syndrome (ARDS) that further progress to cytokine storm syndrome and induced end-organ failure[3]. Interestingly, the United States Food and Drug Administration (USFDA) has approved the drugs such as Remdesivir [4], Bamlanivimab [5], and dexamethasone[6] for the treatment of hospitalized patients with COVID-19. Further, the drugs such as decitabine [7], duvelisib [8], and infliximab [9] are currently under clinical development phase for the treatment of COVID19. In this context, it is well-known that interleukin-6 (IL-6) is a pleiotropic cytokine that plays a pivotal role in immune-regulation, inflammation, and infection [10, 11]. Noteworthy, the elevated levels of IL-6 in the blood is highly correlated with the mortality rate in the COVID-19 infected patients [12]. The activation of the IL-6 amplifier would induce cytokine storm, a hallmark of dysregulated inflammation, and thus inhibition or blockade of IL-6 amplifier would alleviate cytokine storm in COVID-19 [12].In these lines many studies have reported that TCZ administration could stabilize the health status of COVID-19 patients by improving respiratory functions, reducing CRP levels, and improved health deteriorations due to COVID-19 [12]. Besides, there are multiple case study series, retrospective and prospective study reports available on the therapeutic benefits of TCZ in COVID-19. As of now there are five randomized 
medRxiv preprint doi: https://doi.org/10.1101/2021.01.27.21250599; this version posted February 23, 2021. The copyright holder for this preprint (which was not certified by peer review) is the author/funder, who has granted medRxiv a license to display the preprint in perpetuity.

All rights reserved. No reuse allowed without permission.

controlled trials (RCTs) reported on the use of TCZ in COVID-19 (RCT-TCZ-COVID-19 NCT04346355, CORIMUNO-19 NCT04331808, BACC Bay Tocilizumab Trial NCT04356937, COVACTA NCT04320615, REMAP-CAP NCT02735707, and EMPACTA NCT04372186), the low number of subject enrollments In those studies are considered as major limitations and authors have highlighted the need of multicentric RCTs involving a higher number of subjects to determine the safety and efficacy of tocilizumab in COVID-19. In this context, there are several randomized controlled trials registered and under progress to evaluate the clinical benefits of TCZ in alleviating COVID-19 and associated health problems (phase II; NCT04317092, NCT04445272, NCT04377659, NCT04330638, NCT04345445) [13].

With this background, the present study was undertaken to evaluate the clinical benefits of TCZ when administered alone and in combination with standard of care (SOC) and/or placebo in reducing the COVID-19-induced mortality, ICU admissions, MV, LOS, LOS-ICU, superinfections, and pulmonary thrombosis.

\section{Methodology}

A detailed literature search was performed using electronic databases such as PubMed, Science direct, CENTRAL (Cochrane Central Register of Controlled Trials (RCTs), and google scholar to identify the clinical reports (retrospective). The keywords such as 'Coronavirus disease 2019' OR 'Coronavirus infection' OR 'Coronavirus' OR 'SARS COV-2' OR 'nCOV 2019' 'Severe acute respiratory syndrome COV 2' AND ‘Tocilizumab' OR 'Interleukin-6 inhibitors' OR 'Cytokine storm' and 'COVID-19 treatment' were used. Grey (unpublished) literature was searched in the following trial registries: US National Institutes of Health (NIH; https://clinicaltr ials.gov/) and the WHO International Clinical Trials Registry Platform (ICTRP; https://apps.who.int/trialsearch/). Further, the pre-print servers such as Research Square, 
bioRxiv.org, and medRxiv were also considered while searching the grey literature. Besides, authors have approached the domain experts, seeking their suggestions and inputs in identifying the additional studies (if any) relevant to the topic. The search was not restricted to any publication language or status of the trial. Furthermore, the reference lists of all relevant articles were hand-searched to find additional studies. An example of a search strategy using PUBMED and Google Scholar has been highlighted in Annexure 1.

\subsection{Inclusion criteria}

The studies published from 01 January 2020 to $30^{\text {th }}$ September 2020 involving comparison of TCZ group with SOC/control treatment group were included. The studies included in this work involves RT-PCR confirmed cases of COVID-19 (Population), having tocilizumab and corresponding SOC/control as interventions (Intervention), comparison between tocilizumab versus SOC/control (Comparison) for the parameter of interest, the evaluations such as Mortality, ICU admissions, MV, LOS, LOS-ICU, super-infections and pulmonary thrombosis (Outcomes) were included in the study.

\subsection{Exclusion criteria}

1. Studies reporting incomplete data.

2. Single-arm studies.

3. Duplicates, case reports, case series were excluded.

4. In-vitro and pre-clinical studies

5. Studies reporting qualitative outcomes without numerical data

The authors of the shortlisted articles were approached through e-mail wherever additional clarification was required. Such as allocation of subjects to control and treatment group, Baseline evaluations, confounding variables, classification of interventions, if there are nay deviations in 
the intended interventions, measurement of outcomes, data handling, if there is any missing data, reason for missing of data (like selective reporting), treatment details like details of standard of care (SOC) and tocilizumab, the adjustments in the analysis, and so on. The exclusion was executed upon mutual discussion and agreement of all the authors as per exclusion criteria mentioned in the manuscript.

\subsection{Quality assessment and Risk of Bias analysis for included studies}

All the included studies were subjected to the quality assessment using the Newcastle-Ottawa scale and also evaluated for risk of bias using the Cochrane Collaboration tool to assess The Risk of Bias in Non-randomized Studies of Interventions (ROBINS-I).

\subsection{Parameters}

The parameters related to COVID-19 such as Mortality, ICU (intensive care unit) ward admission rate, the need of mechanical ventilation, length of hospital stay (LOS), length of hospital stay in the ICU (LOS-ICU), and the incidences events such as super-infections, fungemia, bacteremia, pneumonia, and pulmonary thrombosis were evaluated as the primary outcomes. The comparison will be between TCZ and standard care/placebo/control.

\subsection{Article selection, Data extraction, and Analysis}

The article selection and data extraction was performed by two reviewers separately based on the inclusion and exclusion criteria listed above. The analysis was carried out at three levels namely on title, abstract and full-text level. Any disagreement was resolved by discussing it with the third reviewer. Two authors have individually extracted the data such as details of participants, methods, interventions, frequency/duration of treatment, outcome measurements, and adverse effects from the included studies. For studies that reported results only in graphical form, numerical values from the graphs were extracted using Adobe ${ }^{\circledR}$ Reader ${ }$ XI inbuilt measuring 
medRxiv preprint doi: https://doi.org/10.1101/2021.01.27.21250599; this version posted February 23, 2021. The copyright holder for this preprint (which was not certified by peer review) is the author/funder, who has granted medRxiv a license to display the preprint in perpetuity. All rights reserved. No reuse allowed without permission.

tool, version 11.0.06, (Adobe Systems Incorporated, San Jose [California]). Any disagreement was resolved by discussing it with the third reviewer.

\subsection{Statistical analysis}

Review Manager (RevMan, version 5.3; Nordic Cochrane Centre [Cochrane Collaboration], Copenhagen, Denmark; 2014) shall be used to analyze the data. For continuous, variables, inverse variance (IV) was estimated using the random-effects model with a mean difference (MD) or standardized mean difference (SMD) as an effect measure and for the dichotomous variables, the Mantel-Haenszel (M-H) statistic was estimated using a random-effects model with an odds ratio (OR) as the effect measure. Heterogeneity shall be calculated with the $I^{2}$ statistic. This test estimates the percentage of variation between study results that is due to heterogeneity rather than sampling error. $I^{2}$ of less than $40 \%$ is considered unimportant while that of more than $40 \%$ is viewed as moderate to considerable heterogeneity.

\section{Results}

A total of 1425 articles were identified based on the online search, of which 24 articles involving 5676 participants were selected for systematic review and meta-analysis (List of excluded studies based on the full-text screening are given in Annexure 2). The PRISMA flow chart of the studies selected is given in Figure 1. Only Retrospective studies were selected for the analysis; the characteristics of the included studies are summarized in Table 1. In all the included studies TCZ was common and the effect of TCZ was compared with the control group; while in few studies, both standard treatment and TCZ groups had background/previously received either antibiotics, antiviral drugs and corticosteroids, and oxygen which are considered as the standard of care (SOC), and in these studies, the comparison was made between TCZ + SOC versus SOC alone, here the SOC alone is considered as placebo. In the studies where multiple doses of TCZ 
was used, the response for mid-dose was considered for analysis. In this study, the parameters such as mortality, ICU ward admission rate, need of mechanical ventilation (MV), Length of Hospital Stay (LOS), Length of Hospital Stay in ICU (LOS-ICU) and incidences of events such as super-infections, fungemia, bacteremia, pneumonia, and pulmonary thrombosis were compared between TCZ treatment versus control/SOC groups in COVID-19 positive patients.

\subsection{Quality assessment and Risk of Bias (RoB):}

All the included studies have passed the quality assessment and showed a low risk of bias. The quality assessment and Risk of Bias (RoB) assessment for all the 24 included observational studies are given in Annexure 3 and $\mathbf{4}$ respectively.

\subsection{Efficacy}

The improvement in the parameters such as mortality, ICU ward admission rate, need of mechanical ventilation (MV), Length of Hospital Stay (LOS), and Length of Hospital Stay in ICU (LOS-ICU) were considered for evaluating and concluding the efficacy of TCZ compared to control group in COVID-19 positive patients.

\subsubsection{Mortality rate}

The COVID-19 positive patients treated with TCZ have shown a mortality rate of $24.3 \%$ (448/1841), whereas the control group received SOC has a mortality rate of $31.2 \%(1079 / 3454)$. The outcomes of the meta-analysis has revealed that the TCZ treatment has reduced the mortality rate (Mantel-Haenszel (M-H), random effects Odds ratio (RE-OR) of 0.56 (0.38 to 0.84), at 95\% CI, $\mathrm{p}=0.005, I^{2}=83 \%$ ) compared to control/SOC. The effect of TCZ on COVID-19 induced mortality of depicted in Figure 2.

\subsubsection{ICU ward admission rate}


medRxiv preprint doi: https://doi.org/10.1101/2021.01.27.21250599; this version posted February 23, 2021. The copyright holder for this preprint (which was not certified by peer review) is the author/funder, who has granted medRxiv a license to display the preprint in perpetuity.

All rights reserved. No reuse allowed without permission.

Six retrospectives studies involving 542 patients in the TCZ treatment and 1595 patients in the control/SOC, with a total of 2137 COVID-19 positive patients were considered for the analysis. The outcomes of the meta-analysis revealed that there is a statistically significant difference observed between the TCZ and control/SOC treatments in reducing the incidences of ICU ward admission rate (M-H, RE-OR of $0.91(0.24$ to 3.44$)$ at $\left.95 \% \mathrm{CI}, \mathrm{p}=0.89, I^{2}=94 \%\right)$. The results are given in Figure 3.

\subsection{3. need of Mechanical ventilation (MV)}

Twelve retrospectives studies involving 756 patients in the TCZ treatment and 1052 patients in the control/SOC, with a total of 1808 COVID-19 positive patients were considered for the analysis. The outcomes have revealed that there is no difference between the TCZ and control/SOC group in the terms of need of mechanical ventilation during the hospitalization (M$\mathrm{H}, \mathrm{RE}-\mathrm{OR}$ of $1.11(0.68$ to 1.81$)$ at $\left.95 \% \mathrm{CI}, \mathrm{p}=0.69, I^{2}=63 \%\right)$. The forest plot analysis is depicted in Figure 4.

\subsubsection{Effect of TCZ on Length of Hospital Stay (LOS)}

The LOS was evaluated by considering the eight retrospective studies comprising of a total of 2030 COVID-19 positive patients, of which 1395 (68.7\%) patients were assigned to the TCZ treatment arm and $635(31.2 \%)$ patients were into the control/SOC group. The results of the meta-analysis showed that there was substantial heterogeneity among the included studies $\left(I^{2}=100 \%\right)$ and there was no statistically significant difference in LOS (days), observed between the TCZ and control/SOC groups (Inverse variance (IV): -2.86 (-0.91 to 3.38) at 95\% CI, p=0.37, $\left.I^{2}=100 \%\right)$. The forest plot analysis for LOS is depicted in Figure 5.

\subsubsection{Effect of TCZ on Length of Hospital stay in ICU (LOS-ICU)}


The LOS-ICU was analyzed using three retrospective studies including a total of 1325 COVID19 positive patients, of which $308(23.2 \%)$ patients were assigned to the TCZ + SOC treatment arm and 1017 (76.8\%) patients were into the control/SOC group. The results of the meta-analysis showed that there was substantial heterogeneity among the included studies $\left(I^{2}=100 \%\right)$ and there was no statistically significant difference in LOS-ICU (days) observed between the TCZ and control/SOC groups (IV: $-3.93(-12.35$ to 4.48$)$ at $\left.95 \% \mathrm{CI}, \mathrm{p}=0.36, I^{2}=100 \%\right)$. The forest plot analysis for LOS is depicted in Figure 6.

\subsubsection{Incidence of Toclimuzab-induced infections}

\subsection{6 a. Super-infections}

The incidence of TCZ-induced super-infections was determined from the eight retrospective studies carried on 1,441 patients out of which $800(55.5 \%)$ were under the control/SOC group and $641(44.4 \%)$ patients were considered under the TCZ group.

The meta-analysis revealed that the chances of super-infections are slightly high in the TCZ treated group compared to control/SOC $\left(\mathrm{M}-\mathrm{H}, \mathrm{RE}-\mathrm{OR}\right.$ of $1.81(1.08,3.01)$ at $95 \% \mathrm{CI}, \mathrm{p}=0.02, I^{2}$ $=60 \%$ ), however, there is a significant heterogenicity among the studies included for the analysis.

\subsection{6 b. Fungemia}

The incidence of TCZ-induced fungemia was determined from the three retrospective studies carried on 392 patients, out of which 194 (49.5\%) were under the control group and 198(50.5\%) patients were assigned under the TCZ group. The meta-analysis revealed that there is no statistically significant difference among the TCZ and control/SOC groups observed in the incidences of fungemia (M-H, RE-OR of $1.73(0.51,5.87)$ at $\left.95 \% \mathrm{CI}, \mathrm{p}=0.38, I^{2}=0 \%\right)$.

\subsection{6 c. Bacteremia}


medRxiv preprint doi: https://doi.org/10.1101/2021.01.27.21250599; this version posted February 23, 2021. The copyright holder for this preprint (which was not certified by peer review) is the author/funder, who has granted medRxiv a license to display the preprint in perpetuity.

All rights reserved. No reuse allowed without permission.

The incidence of TCZ-induced bacteremia was determined from the four retrospective studies carried in 956 patients, out of which $571(59.3 \%)$ patients were under the control/SOC group and $385(40.2 \%)$ patients were assigned under the TCZ group. The outcomes of the meta-analysis showed no difference among the TCZ and control/SOC groups, in the incidences of bacteremia (M-H, RE-OR of $0.92(0.46,1.82)$ at $\left.95 \% \mathrm{CI}, \mathrm{p}=0.80, I^{2}=35 \%\right)$.

\subsection{6 d. Pneumonia}

This parameter was analyzed by considering the four retrospective studies carried on 897 patients, out of which $538(60 \%)$ were under the control group and 359(40\%) patients were assigned into the TCZ group. The outcomes of the analysis revealed that TCZ treated group has more chances of pneumonia compared to the control/SOC group (M-H, RE-OR of 2.44 (1.50, 3.96) at $\left.95 \% \mathrm{CI}, \mathrm{p}=0.0003, I^{2}=0 \%\right)$.

. The forest plot analysis of the incidence of TCZ-induced infections are depicted in Figure 7.

\subsubsection{Incidence of Toclimuzab-induced pulmonary thrombosis}

The incidence of pulmonary thrombosis was determined from the two retrospective studies carried on 193 patients, of which $97(50.3 \%)$ patients were under the control/SOC group and 96(49.7\%) patients were assigned under the TCZ group (received at least one dose of TCZ). The outcomes of the analysis revealed that there was no significant difference in the incidences of pulmonary thrombosis between TCZ and control/SOC treated groups (M-H, fixed effect odds ratio (RE-OR) of $1.01(0.45$ to 2.27$)$ at $\left.95 \% \mathrm{CI}, \mathrm{p}=0.98, I^{2}=0 \%\right)$. The forest plot analysis of the incidence of TCZ-induced pulmonary thrombosis is depicted in Figure 8.

\section{Discussion}

This systematic review and meta-analysis were performed to collect, analyze, interpret and conclude the efficacy and safety of TCZ in the treatment of COVID-19 positive subjects. Since 
the emergence of the pandemic, globally the scientists are in search of a medicine or treatment strategy to combat or manage the pandemic and thereby reduce the social-economic burden throughout the world [14]. Many multi-national organizations, research organizations, and academic researchers are extensively working on developing an effective treatment for COVID19 [15]. As of now, it has been symptomatically managed by using already existing medications such as antivirals (remdesivir, oseltamivir, etc.), anti-pyretic (paracetamol), anti-histaminic (cetirizine,), antibiotics (cephalosporins), corticosteroids (prednisolone, methylprednisolone), monoclonal antibodies (tocilizumab, imatinib) [16]. In this context, the IL-6 antagonists are considered to have better therapeutic benefits in the symptomatic management of COVID-19, in these lines, TCZ is considered as one of the most commonly used medication to suppress the cytokine storm in COVID-19 patients [17]. There are multiple case series, retrospective, and prospective studies available on the therapeutic role of TCZ in COVID-19. Also, there are few meta-analysis reports published related to the therapeutic use of TCZ in COVID-19. However, this study was focused to provide an overall view on the efficacy and safety of TCZ in COVID19 patients considering the retrospective studies/reports available on the topic till October 2020.

Based on the inclusion and exclusion criteria a total of 24 retrospective studies were selected for this study, comprising of 5686 COVID-19 positive patients. The parameters such as mortality, ICU ward admission rate, need of Mechanical ventilation, Length of Hospital Stay, Length of Hospital stay in ICU, Incidence of super-infections such as fungemia, bacteremia, pneumonia, and pulmonary thrombosis were considered for systematic review and meta-analysis.

The available literature favors the benefit of TCZ in minimizing the COVID-19 induced mortality [18, 19, 20, 21]. In this study, 22 included studies have reported mortality as a parameter of which 16 studies have supported the use of TCZ in minimizing the mortality, and 6 
medRxiv preprint doi: https://doi.org/10.1101/2021.01.27.21250599; this version posted February 23, 2021. The copyright holder for this preprint (which was not certified by peer review) is the author/funder, who has granted medRxiv a license to display the preprint in perpetuity.

All rights reserved. No reuse allowed without permission.

studies have shown results in the favor of control. The outcome of the meta-analysis revealed that the administration of TCZ could benefit the COVID-19 positive patients in minimizing the COVID-19 induced mortality.

Further, among the hospitalized COVID-19 positive patients about 5-10\% population requires ICU admission [22,23]. In this regard, some of the available reports have supported the use of TCZ in reducing the incidences of ICU admission [22, 24, 25]. However, the outcomes of the present meta-analysis showed that there is no significant difference between the TCZ and control/SOC groups in the incidences of ICU admission among the COVID-19 infected patients.

Moreover, about $89.9 \%$ of ICU cases and $20.2 \%$ of hospitalized COVID-19 positive patients require mechanical ventilation (Invasive and/or Non-invasive) [26], and the role of TCZ in reducing the need for MV has been evaluated in multiple studies [27, 28, 29,30, 31]. In the present study, 12 retrospective studies reporting the MV as a parameter were included, of these 12 studies, 7 studies have reported in favor of TCZ, 5 studies have reported in the favors of control/SOC and 1 study was neutral. The outcomes of the meta-analysis revealed that the need for MV is the same between TCZ and control/SOC treated groups.

Besides, length of stay (LOS and LOS-ICU) is the one of important parameters considered for evaluating the efficacy in COVID-19 patients. As per the available data, the median LOS was found to be 4 to 21 days (outside China) and median LOS-ICU was found to be 4 to 19 days (outside China) [32]. In this regard, 8 studies reporting LOS and 3 studies reporting LOS-ICU were included in the present study. On the overview, the TCZ treatment has shown benefit in minimizing the LOS and LOZ-ICU compared to control/SOC. However, there was no statistically significant difference observed between the TCZ and control/SOC groups, due to the significant heterogenicity $\left(I^{2}=100 \%\right)$ associated with the included studies. 
On the other hand, the safety of TCZ is the prime concern while administering to COVDI-19 patients. The available literature suggests that TCZ administration can cause adverse (AEs) and serious adverse events (SAEs) such as super-infections, fungemia, bacteremia, pneumonia, pulmonary thrombosis, and so on $[30,33,34,35,36,37]$. Therefore, the incidences of events such as these adverse events were compared between the TCZ and control/SOC treated groups using the 9 included studies. The outcomes of the meta-analysis revealed that the TCZ administration has higher chances of producing the events such as super-infections, fungemia, bacteremia, pneumonia, and pulmonary thrombosis compared to control/SOC.

Further, we found that there are 7 systematic reviews and meta-analyses published based on observational studies on the role of tocilizumab in the treatment of COVID-19 [45, 46, 47, 48,49, 50, 51]. However, a meta-analysis published by Aziz et al [45] has a close association with this meta-analysis. Aziz et al., included 23 studies involving 6279 patients, and the parameters such as mortality, need for mechanical ventilation, ICU admission, and secondary infections were considered as parameters [45]. However, we have included additional parameters such a LOS, LOS-ICU, role of TCZ treatment on incidences of super-infections, and also evaluated the incidences of TCZ-induced pulmonary thrombosis. In addition, our analysis has a greater number of studies in the parameters like mortality and the need for mechanical ventilation. Lastly, in the conclusion section Aziz et al., have stated that TCZ treatment has the potential to decrease the mortality rate in severe COVID-19 patients without causing a significant increase in the infection rate [45].

Commenting on other meta-analysis works, Zhao et. al, have performed a meta-analysis including 10 studies, comprising 1675 patients. Mortality, admission to ICU, safety, and efficacy were considered for analysis. This study has concluded that TCZ treatment could reduce mortality significantly compared to control/SOC in severe COVID-19 patients [46]. Further, the meta-analysis performed by Liu et. al., has included 28 studies consisting of 991 COVID-19 
confirmed patients receiving TCZ. They have concluded that TCZ administration has reduced the death rate in severe COVID-19 cases [47]. Moreover, Surjit Singh et. al have performed a meta-analysis including a total of 13 observational studies comprising 2750 patients. Based on the detailed analysis they have concluded that there is a $46 \%$ decrease in mortality rate, and a $66 \%$ decrease in the progression of diseases in TCZ treated group compared to the SOC group [48]. Besides, based on the meta-analysis of 16 studies Boregowda et. al. have concluded that the addition of TCZ to the standard regimen could reduce the mortality in severe COVID-19 patients [49]. On the other hand, Kotak S et al have carried a meta-analysis including 13 studies consists of a total of 766 patients. Based on the observations, authors have concluded that TCZ is safe and effective in reducing mortality among critically ill COVID-19 patients. However, this study has very limited numbers of observations. However, a systematic review performed by Lan et al. has concluded that the available pieces of evidence are not strong enough to derive a conclusive decision about the benefit of TCZ in treating COVID-19 and associated health complications. They have included 7 retrospective studies comprising of 592 adult COVID-19 patients. [51]. Basides, there is a meta-analysis work published by Tleyjeh et al., wherein authors have included five RCTs of tocilizumab related to its benefits in COVID-19. The outcomes of the metaanalysis (based on RCTs) concludes that TCZ did not reduce the short-term mortality, and cumulative evidences suggest that there is reuction in risk of mechanical ventilation. While, there was difference in the risk of infections or adverse events between the TCZ and SOC groups [52]. The pooled estimated of meta-analysis of RCTs Overall, based on the meta-analysis of moderately-certain evidence we can conclude that the administration of TCZ would reduce the risk of mortality, and however, there is no much difference observed between the TCZ and SOC/control groups in other parameters such as ICU admission rate, need of mechanical 
ventilation and length of hospital stay (ICU and Non-ICU). On the other hand, TCZ treated subjects possess higher chances of adverse events like super-infections, fungemia, bacteremia, pneumonia, and pulmonary thrombosis compared to the control/SOC group.

\section{Conclusions}

This meta-analysis was performed using retrospective clinical reports on the use of TCZ in COVID-19, and based on the outcomes of the meta-analysis we can conclude that administration of TCZ would reduce the risk of mortality, and however, there is no much difference observed between the TCZ and SOC/control groups in other parameters such as ICU admission rate, need of mechanical ventilation and length of hospital stay (ICU and Non-ICU). On the other hand, TCZ treated subjects possess higher chances of super-infections and pneumonia compared with SOC/control group. All the included studies have passed the quality assessment and showed a low risk of bias. However, the major limitation of this study is the significant heterogenicity observed in the outcomes due to multiple confounding factors, and hence there is a need for multi-centric randomized trials involving a large COVID-19 patient population, proper adjustment of confounders like SOC medications to determine the potential therapeutic role of TCZ in mitigating COVID-19 and associated health complications.

\section{Limitations}

Our meta-analysis has many limitations. Firstly, all the included articles are observational studies and the observational studies are not as robust as randomized controlled studies. Secodnly, there was a moderate to significant heterogenicity observed in the outcomes of the various parameters evaluated. Interestingly, the observed heterogenicity between the included studies is due to multiple reasons as highlighted below. All the included studies are observational, and the confounders associated with one or two included studies may also influence the outcomes to a 
large extent. Besides, since there was no specific treatment available for COVID-19 (before the approval of vaccine), the therapies are dynamically evolving with each passing day, therefore the comparator group or standard of care (SOC) or control group has varied significantly from study to study, this is also one of the potential causes for heterogenicity observed. Lastly, there was no standard treatment regimen available for tocilizumab use in the included studies, like there is the difference in dosage regimen (strength and number of doses), route of administration, time of administration, age, and gender difference. These are some of the possible reasons for significant heterogenicity observed in the outcomes of the present study.

Conflicts of Interest statement: Authors declares that they have no conflicts of interest

Funding: The author(s) received no financial support for the research, authorship, and/or publication of this article.

\section{References}

1. Bogoch, II, Watts A, Thomas-Bachli A, Huber C, Kraemer MUG, Khan K. Pneumonia of unknown aetiology in Wuhan, China: potential for international spread via commercial air travel. J Travel Med. 2020;27.

2. World Health Organization. Coronavirus disease 2019 (COVID-19): Situation Report$2020 ; 51$.

3. Zhao S, Lin Q, Ran J, Musa SS, Yang G, Wang W, et al. Preliminary estimation of the basic reproduction number of novel coronavirus (2019-nCoV) in China, from 2019 to 2020: A datadriven analysis in the early phase of the outbreak. Int J Infect Dis. 2020;92:214-214.

4. https://www.health.harvard.edu/diseases-and-conditions/treatments-for-covid-19

5. https://reference.medscape.com/drug/bamlanivimab-4000141

6. https://www.who.int/news-room/q-a-detail/coronavirus-disease-covid-19-dexamethasone 
7. Kantarjian H, Oki Y, Garcia-Manero G, Huang X, O'Brien S, Cortes J, et al. Results of a randomized study of 3 schedules of low-dose decitabine in higher-risk myelodysplastic syndrome and chronic myelomonocyticleukemia. Blood. 2007;109(1):52-7.

8. https://clinicaltrials.gov/ct2/show/NCT04372602.

9. https://clinicaltrials.gov/ct2/show/NCT04425538

10. Shimizu M. Clinical Features of Cytokine Storm Syndrome. In: Cron RQ, Behrens EM, eds. Cytokine Storm Syndrome. Cham, Springer International Publishing, 2019; pp. 31-41.

11. Hoiland RL, Stukas S, Cooper J. Amelioration of COVID-19 related cytokine storm syndrome: Parallels to chimeric antigen receptor-T cell cytokine release syndrome. $\mathrm{Br} \mathrm{J}$ Haematol. 2020;190: e150-e154.

12. Hojyo, S., Uchida, M., Tanaka, K. et al. How COVID-19 induces cytokine storm with high mortality. InflammRegener. 2020;40: 37.

13. https://clinicaltrials.gov/ct2/results?cond=COVID-19

14. Sarkar C, Mondal M, Torequl Islam M, Martorell M, Docea AO, Maroyi A, Sharifi-Rad J and Calina D (2020) Potential Therapeutic Options for COVID-19: Current Status, Challenges, and Future Perspectives. Front. Pharmacol. 11:572870. doi: 10.3389/fphar.2020.572870.

15. https://www.who.int/emergencies/diseases/novel-coronavirus-2019/global-research-onnovel-coronavirus-2019-ncov/solidarity-clinical-trial-for-covid-19-treatments

16. https://www.cdc.gov/coronavirus/2019-ncov/hcp/clinical-guidance-managementpatients.html

17. Guillen L, Padilla S, Fernandez M. Vanesa AV, García JA, Telenti G et al., Preemptive interleukin-6 blockade in patients with COVID-19. Sci Rep 2020;10: 16826. 
18. Andrew IP, Berry DA, Hansen E, Goy AH, Pecora AL, Sinclaire BA, et al. (2020) Hydroxychloroquine and tocilizumab therapy in COVID-19 patients-An observational study. PLoS ONE 15(8): e0237693.

19. Rossi B, Nguyen LS, Zimmermann P, Boucenna F, Dubret L, Baucher L, et al. Effect of Tocilizumab in Hospitalized Patients with Severe COVID-19 Pneumonia: A Case-Control Cohort Study. Pharmaceuticals (Basel, Switzerland). 2020;13(10),317.

20. Zheng KL, Xu Y, Guo YF. Efficacy and safety of tocilizumab in COVID-19 patients. Aging (Albany NY). 2020;12(19):18878-18888.

21. Capra R, De Rossi N, Mattioli F, Romanelli G, Scarpazza C, Sormani MP, et al. Impact of low dose tocilizumab on mortality rate in patients with COVID-19 related pneumonia. Eur J Intern Med. 2020;76:31-35.

22. Moreno-García E, Caballero VR, Albiach L, et al., Tocilizumab is associated with reduction of the risk of ICU admission and mortality in patients with SARS-CoV-2 infection. medRxiv 2020.06.05.20113738.

23. Martínez-Sanz J, Muriel A, Ron R, Herrera S, Pérez-Molina JA, Moreno S, et al. Effects of tocilizumab on mortality in hospitalized patients with COVID-19: a multicentre cohort study. Clin Microbiol Infect. 2020:S1198-743X(20)30573-5.

24. Roumier M, Paule R, Groh M, Vallée A, Ackermann F. Interleukin-6 blockade for severe COVID-19. medRxiv 2020.04.20.20061861.

25. Klopfenstein T, Zayet S, Lohse A. HNF Hospital Tocilizumab multidisciplinary team. Tocilizumab therapy reduced intensive care unit admissions and/or mortality in COVID-19 patients. Med Mal Infect. 2020;50(5):397-400. 
26. Richardson S, Hirsch JS, Narasimhan M, Crawford JM, McGinn T, Davidson KW, et al. Presenting characteristics, comorbidities, and outcomes among 5700 patients hospitalized with COVID-19 in the New York city area. JAMA 2020;323:2052-2059.

27. Rossi B, Nguyen LS, Zimmermann P. Effect of tocilizumab in hospitalized patients with severe pneumonia COVID-19: a cohort study. medRxiv 2020.06.06.20122341.

28. Guaraldi G, Meschiari M, Cozzi-Lepri A. Tocilizumab in patients with severe COVID-19: a retrospective cohort study. Lancet Rheumatol. 2020;2(8):e474-e484.

29. Mikulska M, Nicolini LA, Signori A. Tocilizumab and steroid treatment in patients with severe Covid-19 pneumonia. medRxiv 2020.06.22.20133413.

30. Kewan T, Covut F, Al-Jaghbeer MJ, Rose L, Gopalakrishna KV, Akbik B. Tocilizumab for treatment of patients with severe COVID-19: A retrospective cohort study. EClinicalMedicine. 2020;24:100418.

31. Gokhale Y, Mehta R, Karnik N, Kulkarni U, Gokhale S. Tocilizumab improves survival in patients with persistent hypoxia in severe COVID-19 pneumonia. EClinical Medicine. 2020;24:100467.

32. Rees EM, Nightingale ES, Jafari Y. COVID-19 length of hospital stay: a systematic review and data synthesis. BMC Med. 2020;18: 270.

33. Campochiaro C, Della-Torre E, Cavalli G. Efficacy and safety of tocilizumab in severe COVID-19 patients: a single-centre retrospective cohort study. Eur J Intern Med. 2020;76:43-49.

34. Rojas-Marte G, Khalid M, Mukhtar O. Outcomes in patients with severe COVID-19 disease treated with tocilizumab: a case-controlled study. QJM. 2020;113(8):546-550. 
35. Somers EC, Eschenauer GA, Troost JP. Tocilizumab for treatment of mechanically ventilated patients with COVID-19. Clin Infect Dis. 2020:ciaa954.

36. Canziani LM, Trovati S, Brunetta E, Testa A. Interleukin-6 receptor blocking with intravenous tocilizumab in COVID-19 severe acute respiratory distress syndrome: A retrospective case-control survival analysis of 128 patients. J Autoimmun. 2020;114:102511.

37. Pettit NN, Nguyen CT, Mutlu GM, Wu D, Kimmig L, Pitrak D, et al. Late onset infectious complications and safety of tocilizumab in the management of COVID-19. J Med Virol. 2020:10.1002/jmv.26429.

38. Quartuccio L, Sonaglia A, McGonagle D. Profiling COVID-19 pneumonia progressing into the cytokine storm syndrome: Results from a single Italian Centre study on tocilizumab versus standard of care. J Clin Virol. 2020; 129:104444.

39. Colaneri M, Bogliolo L, Valsecchi P. Tocilizumab for Treatment of Severe COVID-19 Patients: Preliminary Results from SMAtteo COvid19 REgistry (SMACORE). Microorganisms. 2020;8(5):695.

40. Wadud N, Ahmed N, Shergil M. Improved survival outcome in SARs-CoV-2 (COVID-19) Acute Respiratory Distress Syndrome patients with Tocilizumab administration. medRxiv 2020.05.13.20100081.

41. De Rossi N, Scarpazza C, Filippini C. Early use of low dose tocilizumab in patients with COVID-19: A retrospective cohort study with a complete follow-up. EClinical Medicine. 2020;25:100459. 
42. Moreno-Pérez O, Andres M, Leon-Ramirez JM, Sánchez-Payá J, Rodríguez JC, Sánchez R, et al. Experience with tocilizumab in severe COVID-19 pneumonia after 80 days of followup: A retrospective cohort study. J Autoimmun. 2020;114:102523.

43. Ramaswamy M, Mannam P, Comer R, Sinclair E, McQuaid DB, Schmidt ML. Off-Label Real World Experience Using Tocilizumab for Patients Hospitalized with COVID-19 Disease in a Regional Community Health System: A Case-Control Study. medRxiv 2020.05.14.20099234.

44. Biran N, Ip A, Ahn J. Tocilizumab among patients with COVID-19 in the intensive care unit: a multicentre observational study. Lancet Rheumatol. 2020;2(10):e603-e612.

45. Aziz M, Haghbin H, Abu Sitta E. Efficacy of tocilizumab in COVID-19: A systematic review and meta-analysis. J Med Virol. 2021; 93:1620-1630.

46. Zhao J, Cui W, Tian BP. Efficacy of tocilizumab treatment in severely ill COVID-19 patients. Crit Care. 2020 ;24(1):524.

47. Liu L, Zong S, Li J. Efficacy and safety of tocilizumab in COVID-19 patients: A MetaAnalysis. Research Square; 2020. DOI: 10.21203/rs.3.rs-50446/v1

48. Surjit Singh, Daisy Khera, Ankita Chugh, Niti Mittal, Rakesh Mittal, Vinay Kumar Chugh. Efficacy and Safety of Tocilizumab in the Treatment of SARS-CoV-2: A Systematic Review and Meta-analysis. Research Square DOI: https://doi.org/10.21203/rs.3.rs-59511/v1

49. Boregowda U, Perisetti A, Nanjappa A, Gajendran M, Kutti Sridharan G, Goyal H. Addition of Tocilizumab to the Standard of Care Reduces Mortality in Severe COVID-19: A Systematic Review and Meta-Analysis. Front Med (Lausanne). 2020;7:586221. 
medRxiv preprint doi: https://doi.org/10.1101/2021.01.27.21250599; this version posted February 23, 2021. The copyright holder for this preprint

(which was not certified by peer review) is the author/funder, who has granted medRxiv a license to display the preprint in perpetuity. All rights reserved. No reuse allowed without permission.

50. Kotak S, Khatri M, Malik M, Malik M, Hassan W, Amjad A, et al. Use of Tocilizumab in COVID-19: A Systematic Review and Meta-Analysis of Current Evidence. Cureus. 2020;12(10):e10869.

51. Lan SH, Lai CC, Huang HT, Chang SP, Lu LC, Hsueh PR. Tocilizumab for severe COVID19: a systematic review and meta-analysis. Int J Antimicrob Agents. 2020;56(3):106103.

52. Tleyjeh IM, Kashour Z, Damlaj M, Riaz M, Tlayjeh H, Altannir M, et al. Efficacy and safety of tocilizumab in COVID-19 patients: a living systematic review and meta-analysis. Clin Microbiol Infect. 2021;27(2):215-227. 
medRxiv preprint doi: https://doi.org/10.1101/2021.01.27.21250599; this version posted February 23, 2021. The copyright holder for this preprint (which was not certified by peer review) is the author/funder, who has granted medRxiv a license to display the preprint in perpetuity. All rights reserved. No reuse allowed without permission.

\section{Figure captions}

Figure 1. PRISMA Flow chart

Figure 2. Effect of Tocilizumab on COVID-19 mortality

Figure 3. Effect of Tocilizumab on COVID-19 related ICU ward admission rate

Figure 4. Effect of Tocilizumab on the need of Mechanical ventilation in COVID-19 patients

Figure 5. Effect of Tocilizumab on Length of Hospital Stay (LOS) in COVID-19 patients

Figure 6. Effect of Tocilizumab on Length of Hospital Stay in ICU (LOS-ICU) in COVID-19 patients

Figure 7. The incidences of Toclimuzab-induced super-infections in COVID-19 patients

Figure 8. The incidents of Toclimuzab-induced pulmonary thrombosis in COVID-19 patients 
medRxiv preprint doi: https://doi.org/10.1101/2021.01.27.21250599; this version posted February 23, 2021. The copyright holder for this preprint (which was not certified by peer review) is the author/funder, who has granted medRxiv a license to display the preprint in perpetuity.

All rights reserved. No reuse allowed without permission.

Figure 1. PRISMA Flow diagram

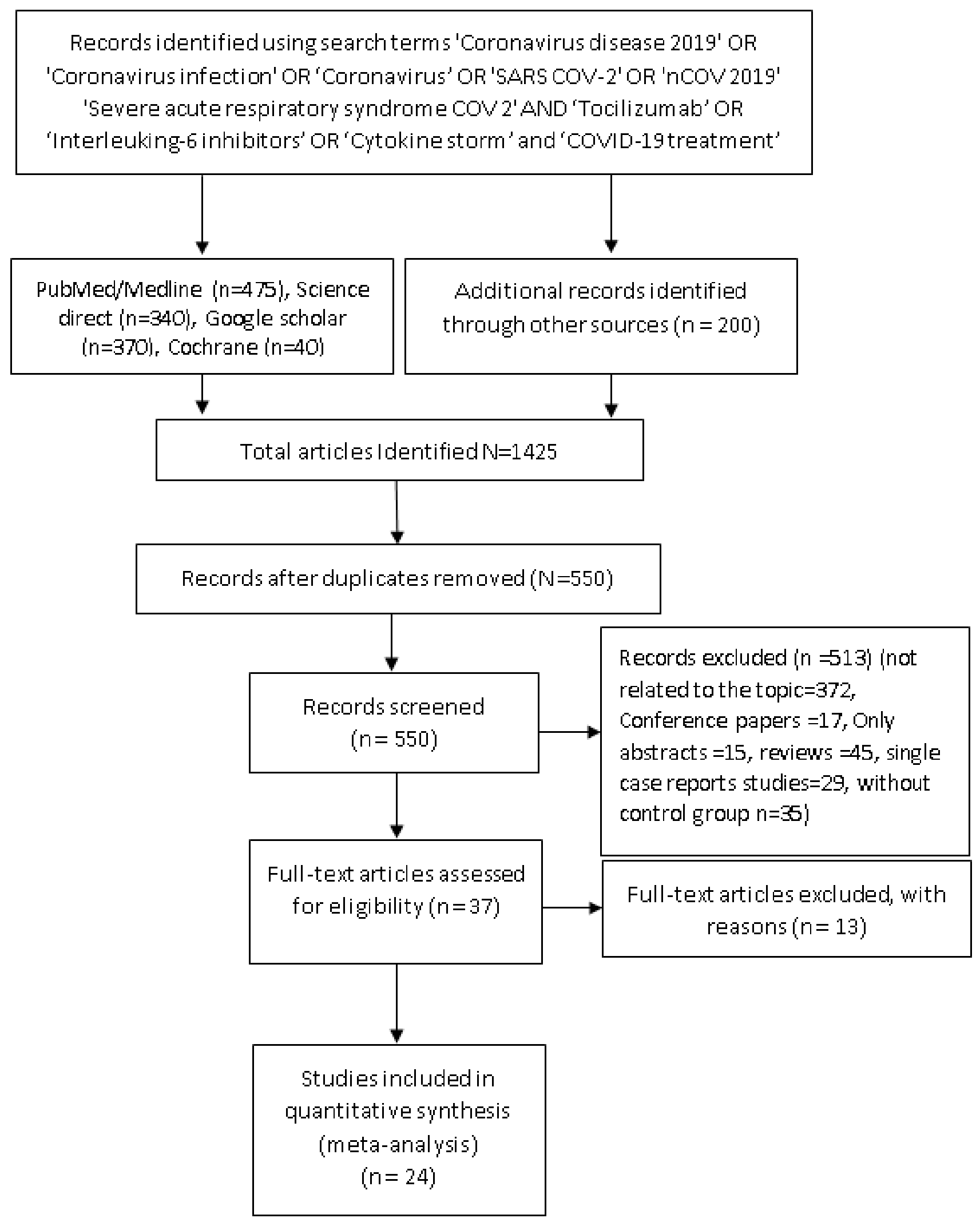




\section{Figure 2. Effect of Tocilizumab on COVID-19 mortality}

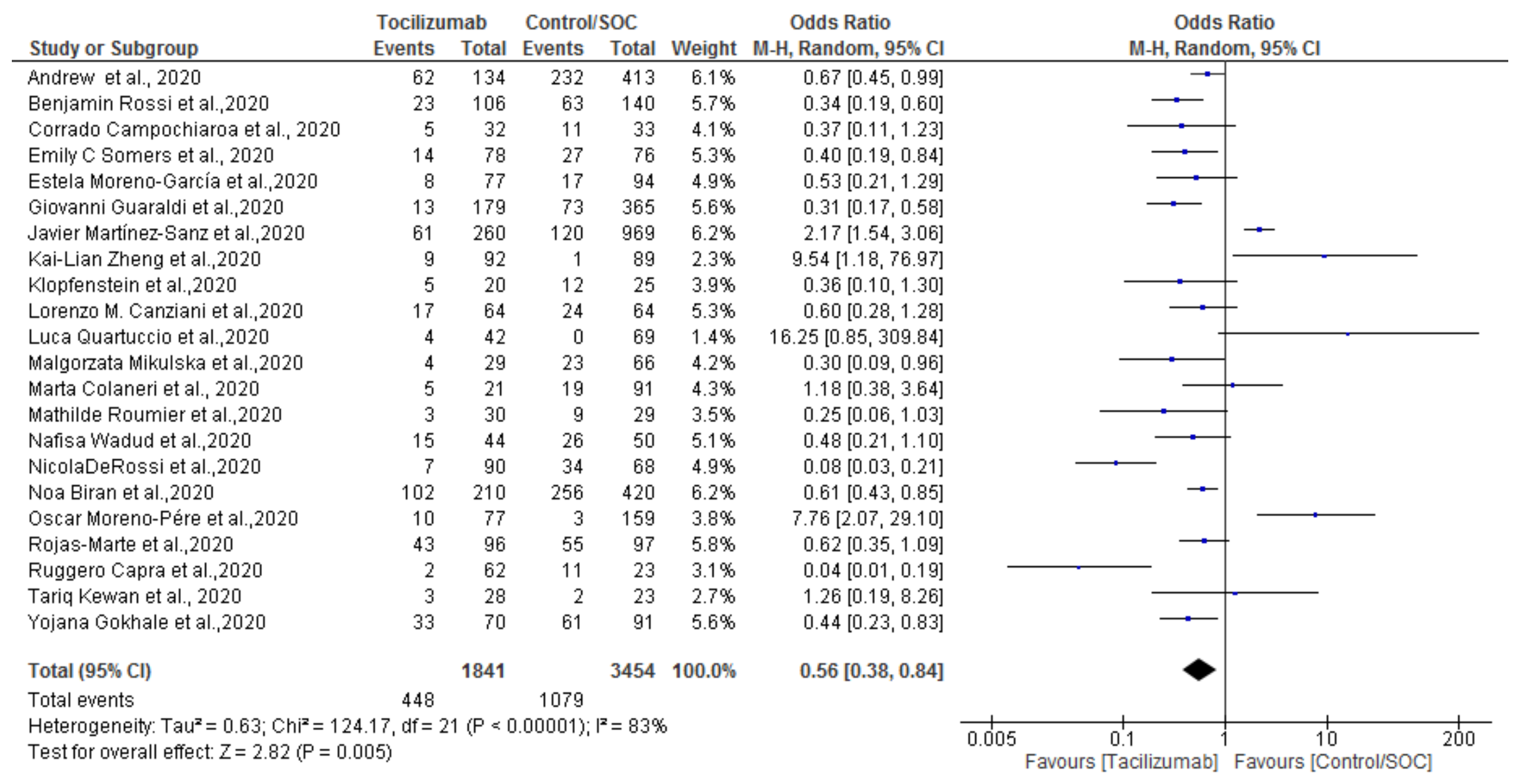


Figure 3. Effect of Tocilizumab on COVID-19 related ICU ward admission rate

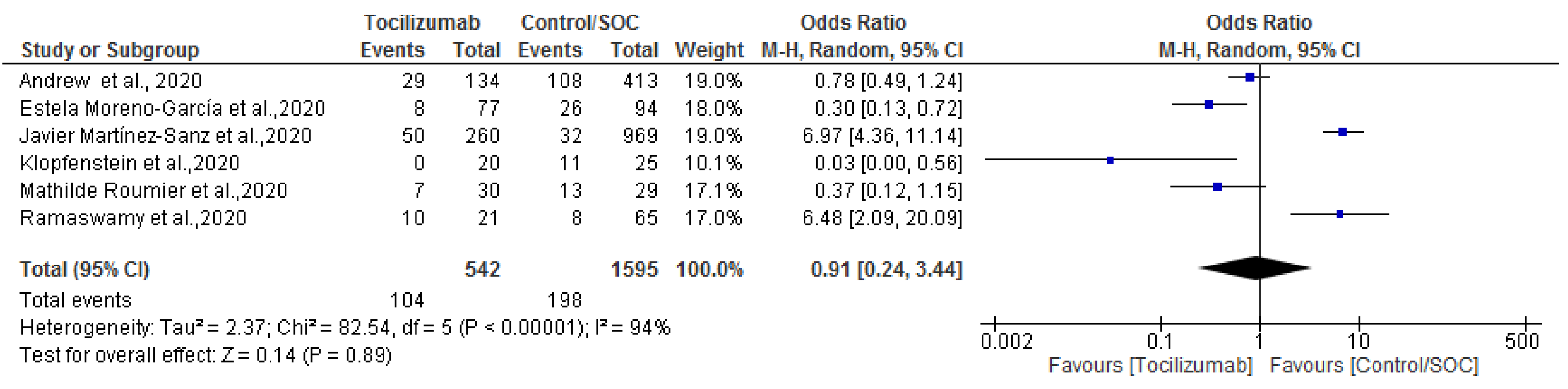


Figure 4. Effect of Tocilizumab on need of Mechanical ventilation in COVID-19 patients

Study or Subgroup

Benjamin Rossi et al.,2020

Corrado Campochiaroa et al., 2020

Estela Moreno-García et al.,2020

Giovanni Guaraldi et al.,2020

Klopfenstein et al.,2020

Malgorzata Mikulska et al.,2020

Mathilde Roumier et al.,2020

Natasha N. Pettit et al.,2020

NicolaDeRossi et al.,2020

Ramaswamy et al.,2020

Tariq Kewan et al., 2020

Yojana Gokhale et al.,2020

\section{Total $(95 \% \mathrm{Cl})$}

Total events

Heterogeneity: $\operatorname{Tau}^{2}=0.42 ; \mathrm{Chi}^{2}=30.10, \mathrm{df}=11(\mathrm{P}=0.002) ; \mathrm{I}^{2}=63 \%$

Test for overall effect: $Z=0.40(P=0.69)$

188
Odds Ratio

Events Total Events Total Weight M-H, Random, $95 \% \mathrm{Cl}$

$140 \quad 8.3 \% \quad 0.82[0.26,2.57]$

$0.33[0.01,8.49]$

$0.23[0.06,0.84]$

$1.22[0.76,1.96]$

$0.05[0.00,0.93]$

$1.02[0.40,2.60]$

$0.41[0.14,1.17]$

$0.88[0.44,1.76]$

$1.74[0.63,4.86]$

$3.64[1.27,10.39]$

3.27 [1.00, 10.69]

$3.39[1.43,8.08]$

$1.11[0.68,1.81]$

$1052100.0 \%$

$689.1 \%$

$65 \quad 8.9 \%$

$23 \quad 8.1 \%$

$10.3 \%$

.

\section{$1.11[0.68,1.81]$}

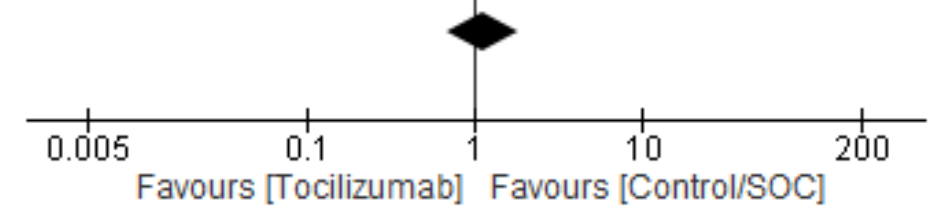




\section{Figure 5. Effect of Tocilizumab on Length of Hospital Stay (LOS) in COVID-19 patients}

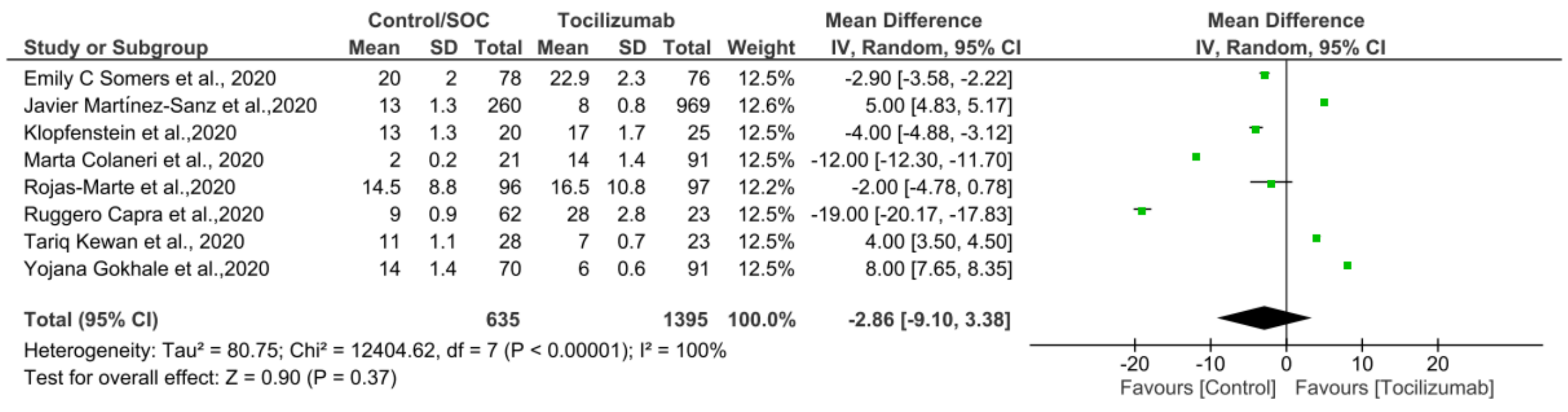


Figure 6. Effect of Tocilizumab on Length of Hospital Stay in ICU (LOS-ICU) in COVID-19 patients

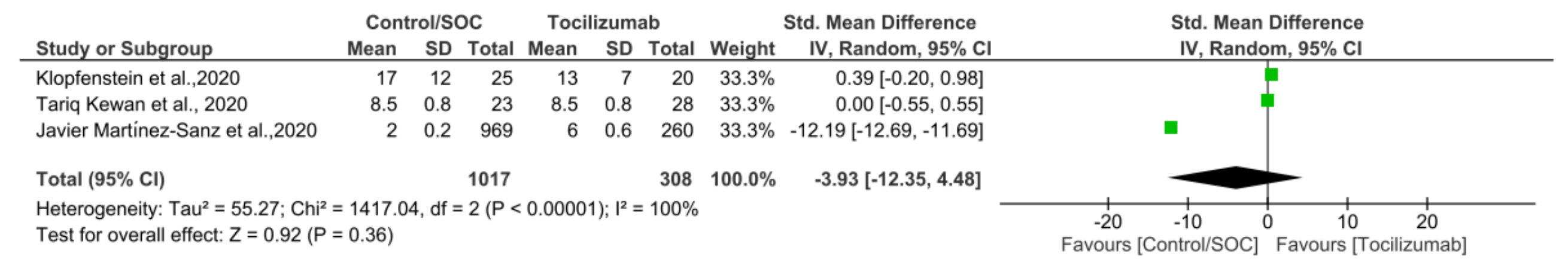


medRxiv preprint doi: https://doi.org/10.1101/2021.01.27.21250599; this version posted February 23, 2021. The copyright holder for this preprint (which was not certified by peer review) is the author/funder, who has granted medRxiv a license to display the preprint in perpetuity.

All rights reserved. No reuse allowed without permission.

\section{Figure 7. The incidences of Toclimuzab-induced super-infections in COVID-19 patients}

\begin{tabular}{lrrrrrr} 
& \multicolumn{7}{c}{ Tocilizumab } & \multicolumn{2}{c}{ Control/SOC } \\
Study or Subgroup & Events & Total & Events & Total & Weight \\
\hline 1.19.1 Superlnfections & & & & & & \\
Corrado Campochiaroa et al., 2020 & 4 & 32 & 4 & 33 & $7.8 \%$ \\
Emily C Somers et al., 2020 & 42 & 78 & 20 & 76 & $15.9 \%$ \\
Giovanni Guaraldi et al.,2020 & 24 & 179 & 14 & 365 & $15.8 \%$ \\
Lorenzo M. Canziani et al.,2020 & 20 & 64 & 25 & 64 & $15.3 \%$ \\
Natasha N. Pettit et al.,2020 & 17 & 74 & 6 & 74 & $12.0 \%$ \\
NicolaDeRossi et al.,2020 & 6 & 90 & 4 & 68 & $9.1 \%$ \\
Rojas-Marte et al.,2020 & 26 & 96 & 16 & 97 & $15.6 \%$ \\
Tariq Kewan et al., 2020 & 5 & 28 & 5 & 23 & $8.4 \%$ \\
Subtotal (95\% Cl) & & 641 & & 800 & $100.0 \%$ \\
Total events & 144 & & 94 & &
\end{tabular}

Heterogeneity: $\operatorname{Tau}^{2}=0.31 ; \mathrm{Chi}^{2}=17.70, \mathrm{df}=7(\mathrm{P}=0.01) ; \mathrm{I}^{2}=60 \%$

Test for overall effect: $Z=2.26(P=0.02)$

\subsubsection{Fungemia}

Natasha N. Pettit et al.,2020

Rojas-Marte et al.,2020

Tariq Kewan et al., 2020

Subtotal $(95 \% \mathrm{Cl})$

Total events

Heterogeneity: Tau $^{2}=0.00 ; \mathrm{Chi}^{2}=1.76, \mathrm{df}=2(\mathrm{P}=0.42) ; \mathrm{I}^{2}=0 \%$

Test for overall effect: $Z=0.88(P=0.38)$

\subsubsection{Bacteremia}

Corrado Campochiaroa et al., 2020

Emily c Somers et al., 2020

Giovanni Guaraldi et al.,2020

Rojas-Marte et al.,2020

Subtotal $(95 \% \mathrm{Cl})$

Total events

Heterogeneity: $\operatorname{Tau}^{2}=0.17 ; \mathrm{Chi}^{2}=4.65, \mathrm{df}=3(\mathrm{P}=0.20) ; \mathrm{I}^{2}=35 \%$

Test for overall effect: $Z=0.25(P=0.80)$

\subsubsection{Pneumonia}

Emily C Somers et al., 2020

Giovanni Guaraldi et al.,2020

Natasha N. Pettit et al.,2020

Tariq Kewan et al., 2020

Subtotal $(95 \% \mathrm{Cl})$

Total events

$\begin{array}{rrrrr}4 & 74 & 0 & 74 & 17.2 \% \\ 4 & 96 & 3 & 97 & 64.1 \% \\ 1 & 28 & 1 & 23 & 18.6 \% \\ & 198 & & 194 & 100.0 \%\end{array}$

$9.51[0.50,179.87]$
$1.36[0.30,6.26]$
$0.81[0.05,13.79]$
$1.73[0.51,5.87]$

$1.04[0.24,4.55]$

$1.55[0.59,4.02]$

$1.54[0.34,6.95]$

$0.46[0.21,0.99]$

$0.92[0.46,1.82]$

$\begin{array}{rrrrr}42 & 78 & 22 & 76 & 53.0 \% \\ 9 & 179 & 7 & 365 & 23.3 \% \\ 7 & 74 & 5 & 74 & 16.4 \% \\ 4 & 28 & 2 & 23 & 7.3 \% \\ & 359 & & 538 & 100.0 \%\end{array}$
36

$0 \%$
$2.86[1.47,5.58]$

$2.71[0.99,7.39]$

$1.44[0.44,4.77]$

$1.75[0.29,10.54]$

$2.44[1.50,3.96]$
Odds Ratio

M-H, Random, $95 \% \mathrm{Cl}$

Heterogeneity: $\mathrm{Tau}^{2}=0.00 \cdot \mathrm{Chi}^{2}=1.14 \mathrm{df}=3(\mathrm{P}=0.77) ; \mathrm{I}^{2}=0 \%$

Test for overall effect: $Z=3.60(P=0.0003)$

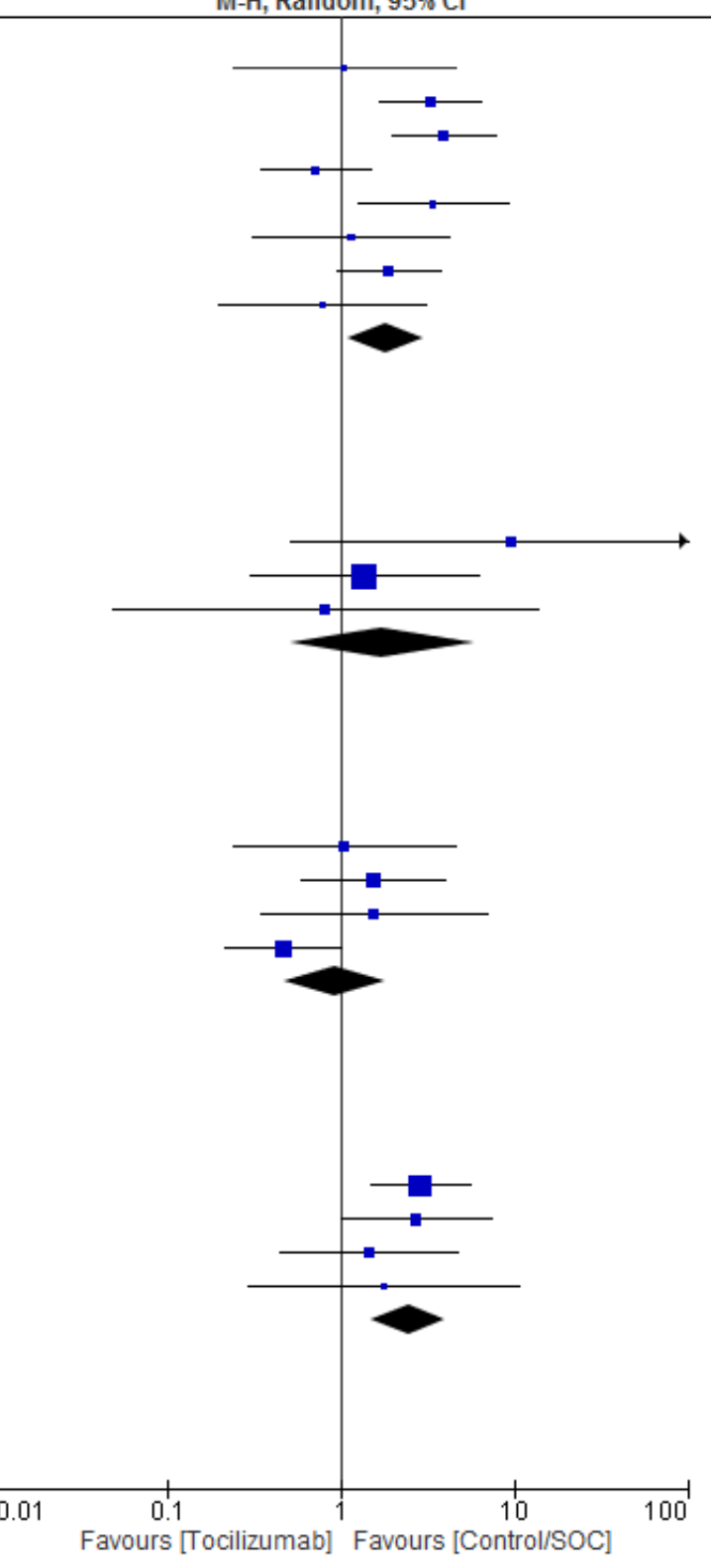


2

Tocilizumab Control/SOC Odds Ratio

Odds Ratio

Study or Subgroup

Events Total Events Total Weight M-H, Random, $95 \% \mathrm{Cl}$

M-H, Random, $95 \% \mathrm{Cl}$

Corrado Campochiaroa et al., 2020

Lorenzo M. Canziani et al.,2020

$\begin{array}{lllll}2 & 32 & 3 & 33 & 19.1 \%\end{array}$

12

$\begin{array}{llll}64 & 11 & 64 & 80.9 \%\end{array}$

$0.67[0.10,4.28]$

$1.11[0.45,2.74]$

Total 5 (95\% Cl)

96

$97 \quad 100.0 \%$

$1.01[0.45,2.27]$

Total events

$14 \quad 14$

Heteregeneity: $\operatorname{Tau}^{2}=0.00 ; \mathrm{Chi}^{2}=0.24, \mathrm{df}=1(\mathrm{P}=0.63) ; \mathrm{I}^{2}=0 \%$

Test for overall effect: $Z=0.02(P=0.98)$

7

8

9

10

11

12

13

14

15

16

17

18 


\begin{tabular}{|c|c|c|}
\hline SI No. & Search Terms & Results \\
\hline 1 & $\begin{array}{c}\text { 'Coronavirus disease 2019' OR 'Coronavirus infection' OR 'Coronavirus' OR 'SARS COV- } \\
\text { 2' OR 'nCOV 2019' 'Severe acute respiratory syndrome COV 2' }\end{array}$ & 112565 \\
\hline 2 & 'Tocilizumab' OR 'Interleukin-6 inhibitors' OR 'Cytokine storm' OR 'COVID-19 \\
treatment' & 613 \\
\hline 3 & 1 AND 2 & 550 \\
\hline 4 & 3 NOT ('Meta-analysis' OR 'Practice guideline' OR 'Systematic review' OR) & 475 \\
\hline 5 & 4 NOT ('Newsletters' OR 'Commentaries' OR 'Opinions' OR 'Editorial' OR 'letter to the \\
\end{tabular}

3

\section{Search strategy using GOOGLE SCHOLAR}

\begin{tabular}{|c|c|c|}
\hline Sl No. & Search Terms & Results \\
\hline 1 & $\begin{array}{l}\text { 'Coronavirus disease 2019' OR 'Coronavirus infection' OR 'Coronavirus' OR 'SARS COV- } \\
\text { 2' OR 'nCOV 2019' 'Severe acute respiratory syndrome COV 2' }\end{array}$ & 2013421 \\
\hline 2 & $\begin{array}{l}\text { 'Tocilizumab’ OR ‘Interleukin-6 inhibitors’ OR ‘Cytokine storm’ OR ‘COVID-19 } \\
\text { treatment' }\end{array}$ & 18252 \\
\hline 3 & 1 AND 2 & 578 \\
\hline 4 & 3 NOT ('Meta-analysis' OR 'Practice guideline' OR 'Systematic review' OR) & 441 \\
\hline 5 & $\begin{array}{l}4 \text { NOT ('Newsletters' OR 'Commentaries' OR 'Opinions' OR 'Editorial' OR 'letter to the } \\
\text { editor' OR 'Short survey') }\end{array}$ & 370 \\
\hline
\end{tabular}




\begin{tabular}{|c|c|c|c|}
\hline $\begin{array}{l}\text { Sl. } \\
\text { No. }\end{array}$ & $\begin{array}{l}\text { First author- } \\
\text { name }\end{array}$ & Title & Reason for exclusion \\
\hline 1 & Betul Borku et al., & $\begin{array}{l}\text { Tocilizumab challenge: A series of cytokine storm therapy } \\
\text { experiences in hospitalized COVID-19 pneumonia patients }\end{array}$ & 1.No control group \\
\hline 2 & $\begin{array}{l}\text { Federico Alberici } \\
\text { et al., }\end{array}$ & $\begin{array}{l}\text { Management of Patients on Dialysis and With Kidney } \\
\text { Transplantation During the SARS-CoV-2 (COVID-19) Pandemic in } \\
\text { Brescia, Italy }\end{array}$ & $\begin{array}{l}\text { 1.No numerical data } \\
\text { reported }\end{array}$ \\
\hline 3 & $\begin{array}{l}\text { Marcus R. Pereira } \\
\text { et al., }\end{array}$ & $\begin{array}{l}\text { COVID-19 in solid organ transplant recipients: Initial report from } \\
\text { the US epicenter }\end{array}$ & $\begin{array}{l}\text { 1. Patients have a history } \\
\text { of solid organ transplant } \\
\text { 2.No control group }\end{array}$ \\
\hline 4 & Marfella et al., & $\begin{array}{l}\text { Negative impact of hyperglycemia on tocilizumab therapy in } \\
\text { Covid-19 patients }\end{array}$ & $\begin{array}{l}\text { 1. Evaluations related to } \\
\text { glycaemic control in the } \\
\text { diabetic population } \\
\text { 2. No control group } \\
\text { 3. No numerical data }\end{array}$ \\
\hline 5 & $\begin{array}{l}\text { Maria Mazzitelli } \\
\text { et al., }\end{array}$ & $\begin{array}{l}\text { Use of subcutaneous tocilizumab in patients with COVID-19 } \\
\text { pneumonia }\end{array}$ & $\begin{array}{l}\text { 1.No numerical data } \\
\text { 2.No control group }\end{array}$ \\
\hline 6 & $\begin{array}{l}\text { Nahéma Issa et } \\
\text { al., }\end{array}$ & Feasibility of Tocilizumab in ICU patients with COVID-19 & $\begin{array}{l}\text { 1.No control group } \\
\text { 2. Only biochemical } \\
\text { parameters are } \\
\text { considered, which are out } \\
\text { of the scope of the } \\
\text { present review. }\end{array}$ \\
\hline 7 & Nan Yu et al., & $\begin{array}{l}\text { Clinical features and obstetric and neonatal outcomes of pregnant } \\
\text { patients with COVID-19 in Wuhan, China: a retrospective, single- } \\
\text { center, descriptive study, March 24, 2020: 30176-6. } \\
\text { http://doi.org/10.1016/S1473-3099(20)30176-6. }\end{array}$ & $\begin{array}{l}\text { 1.Case series without a } \\
\text { parallel control }\end{array}$ \\
\hline 8 & Pan Luo et al., & Tocilizumab treatment in COVID-19: A single-center experience & $\begin{array}{l}\text { 1. Case series without a } \\
\text { control group. } \\
\text { 2. Only CRP and IL-6 } \\
\text { were considered as } \\
\text { parameters, which are not }\end{array}$ \\
\hline
\end{tabular}




\begin{tabular}{|l|l|l|l|}
\hline & & & $\begin{array}{l}\text { out of the scope of the } \\
\text { present review. }\end{array}$ \\
\hline 9 & Patel K et al., & $\begin{array}{l}\text { Use of the IL-6R antagonist tocilizumab in hospitalized COVID-19 } \\
\text { patients. }\end{array}$ & 1 . No control group \\
\hline 10 & Şiran Keske et al., & Appropriate use of tocilizumab in COVID-19 infection & 1 . No control group \\
\hline 11 & Timothy et al., & $\begin{array}{l}\text { Tocilizumab for severe COVID-19 pneumonia: Case series of 5 } \\
\text { Australian patients }\end{array}$ & $\begin{array}{l}1 . \text { Case series without } \\
\text { parallel control. }\end{array}$ \\
\hline 12 & $\begin{array}{l}\text { Tomasiewicz et } \\
\text { al., }\end{array}$ & $\begin{array}{l}\text { Tocilizumab for patients with severe COVID-19: a retrospective, } \\
\text { multi-center study }\end{array}$ & $\begin{array}{l}\text { 2. The parameters } \\
\text { evaluated are out of the } \\
\text { scope of the present } \\
\text { review. }\end{array}$ \\
\hline 13 & $\begin{array}{l}\text { Xu X et al., } \\
\text { 1. No control group } \\
\text { 2. The parameters } \\
\text { evaluated are out of the } \\
\text { scope of the present } \\
\text { review }\end{array}$ \\
\hline
\end{tabular}


1 Annexure 3. Quality assessment of Included papers by Newcastle-Ottawa scale (NOS)

\begin{tabular}{|c|c|c|c|c|c|c|c|c|c|c|c|}
\hline \multirow{2}{*}{$\begin{array}{l}\text { Sl. } \\
\text { N o }\end{array}$} & \multirow[t]{2}{*}{ Included Studies } & \multicolumn{4}{|c|}{ Selection } & \multirow{2}{*}{ 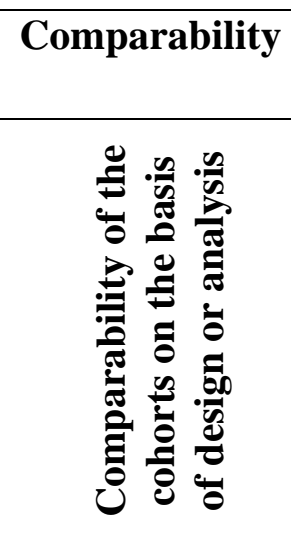 } & \multicolumn{3}{|c|}{ Outcome } & \multirow{2}{*}{$\begin{array}{l}\text { Quality } \\
\text { score }\end{array}$} & \multirow{2}{*}{$\begin{array}{l}\text { Study } \\
\text { rating }\end{array}$} \\
\hline & & 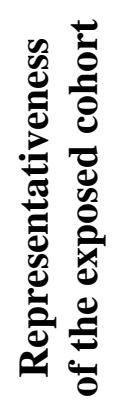 & 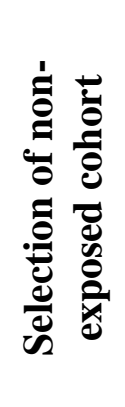 & 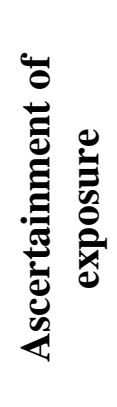 & 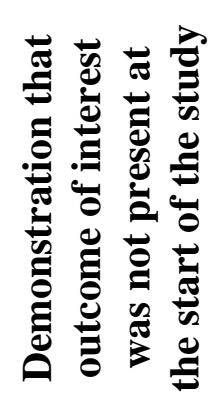 & & 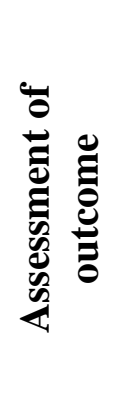 & 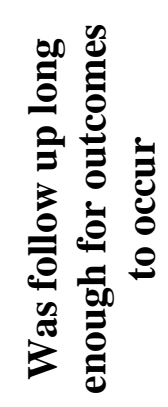 & 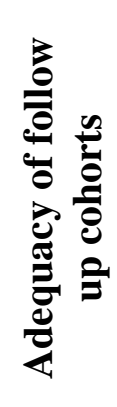 & & \\
\hline 1 & Andrew IP et al., 2020 [18] & 1 & 0 & 1 & 1 & 1 & 1 & 1 & 0 & 6 & Good \\
\hline 2 & Biran N et al.,2020[44] & 1 & 1 & 0 & 1 & 1 & 0 & 1 & 1 & 6 & Fair \\
\hline 3 & Campochiaro C et al., 2020 [33] & 1 & 0 & 1 & 1 & 1 & 1 & 1 & 1 & 7 & Good \\
\hline 4 & Canziani LM et al.,2020[36] & 1 & 0 & 1 & 1 & 1 & 1 & 1 & 1 & 7 & Fair \\
\hline 5 & Capra R et al.,2020[21] & 1 & 1 & 1 & 1 & 1 & 1 & 1 & 1 & 8 & Good \\
\hline 6 & Colaneri M et al., 2020 [39] & 1 & 1 & 1 & 1 & 1 & 1 & 0 & 0 & 6 & Fair \\
\hline 7 & De Rossi N et al.,2020 [41] & 1 & 0 & 1 & 1 & 1 & 0 & 1 & 1 & 6 & Fair \\
\hline 8 & Gokhale Y et al.,2020 [31] & 1 & 1 & 1 & 1 & 1 & 1 & 1 & 0 & 7 & Good \\
\hline 9 & Guaraldi $\mathrm{G}$ et al.,2020[28] & 1 & 0 & 1 & 1 & 1 & 1 & 0 & 1 & 6 & Fair \\
\hline 10 & Kewan T et al., 2020 [30] & 1 & 0 & 1 & 1 & 1 & 1 & 0 & 1 & 6 & Fair \\
\hline 11 & Klopfenstein T et al.,2020[25] & 1 & 1 & 1 & 1 & 1 & 1 & 0 & 1 & 7 & Good \\
\hline
\end{tabular}




\begin{tabular}{|c|c|c|c|c|c|c|c|c|c|c|c|}
\hline 12 & Martínez-Sanz J et al.,2020 [23] & 1 & 1 & 1 & 1 & 1 & 1 & 0 & 1 & 7 & Good \\
\hline 13 & Mikulska M et al.,2020 [29] & 1 & 1 & 1 & 1 & 1 & 1 & 1 & 1 & 8 & Good \\
\hline 14 & Moreno-García E et al.,2020 [ 22] & 0 & 1 & 1 & 1 & 1 & 1 & 1 & 1 & 7 & Good \\
\hline 15 & Moreno-Pérez O et al.,2020 [42] & 1 & 1 & 1 & 1 & 1 & 0 & 0 & 1 & 6 & Fair \\
\hline 16 & Pettit NN et al.,2020 [37] & 1 & 0 & 1 & 1 & 0 & 1 & 1 & 1 & 6 & Poor \\
\hline 17 & Quartuccio L et al.,2020[38] & 1 & 1 & 1 & 0 & 1 & 0 & 1 & 1 & 6 & Fair \\
\hline 18 & Ramaswamy M et al.,2020 [43] & 0 & 1 & 1 & 0 & 1 & 1 & 1 & 1 & 6 & Fair \\
\hline 19 & Rojas-Marte G et al.,2020 [34] & 1 & 0 & 1 & 0 & 1 & 1 & 1 & 1 & 5 & Fair \\
\hline 20 & Rossi B et al.,2020[19] & 0 & 1 & 0 & 1 & 1 & 1 & 1 & 1 & 6 & Good \\
\hline 21 & Roumier M et al.,2020 [24] & 1 & 0 & 1 & 1 & 0 & 1 & 1 & 1 & 6 & Poor \\
\hline 22 & Somers EC et al., 2020 [35] & 0 & 1 & 1 & 0 & 1 & 1 & 1 & 0 & 6 & Fair \\
\hline 23 & Wadud $\mathrm{N}$ et al.,2020 [40] & 1 & 0 & 1 & 1 & 1 & 0 & 1 & 1 & 6 & Fair \\
\hline 24 & Zheng KL et al.,2020 [20] & 1 & 1 & 1 & 1 & 1 & 0 & 1 & 1 & 7 & Good \\
\hline
\end{tabular}

Notel

Quaßity assessment or rating of status based on NOS and Thresholds for converting the NOS to AHRQ standards (good, fair, and poor)

1.Good quality: 3 or 4 stars in Selection domain AND 1 or 2 stars in Comparability domain AND 2 or 3 stars in Outcome/Exposure domain

2.Fałr quality: 2 stars in Selection domain AND 1 or 2 stars in Comparability domain AND 2 or 3 stars in Outcome/Exposure domain

3.Poør quality: 0 or 1 star in Selection domain OR 0 stars in Comparability domain OR 0 or 1 stars in Outcome/Exposure domain.

6

\section{Reference}

https8//www.ncbi.nlm.nih.gov/books/NBK115843/bin/appe-fm3.pdf 


\begin{tabular}{|c|c|c|c|c|c|c|c|c|c|}
\hline \multirow[b]{2}{*}{$\begin{array}{l}\text { Sl. } \\
\text { No }\end{array}$} & \multirow[b]{2}{*}{$\begin{array}{l}\text { Included } \\
\text { Studies }\end{array}$} & \multicolumn{7}{|c|}{ Bias Domains } & \multirow[b]{2}{*}{$\begin{array}{c}\text { Overall RoB } \\
\text { Judgment }\end{array}$} \\
\hline & & $\begin{array}{l}\text { Confoun } \\
\text { ding }\end{array}$ & $\begin{array}{l}\text { Selection of } \\
\text { participants } \\
\text { into the } \\
\text { study } \\
\text { At } \\
\text { intervention }\end{array}$ & $\begin{array}{c}\text { Classification } \\
\text { of } \\
\text { interventions }\end{array}$ & $\begin{array}{c}\text { Deviation } \\
\text { from } \\
\text { intended } \\
\text { interventions }\end{array}$ & $\begin{array}{l}\text { Missing } \\
\text { Data }\end{array}$ & $\begin{array}{c}\text { Measure } \\
\text { ment } \\
\text { of } \\
\text { Outcomes }\end{array}$ & $\begin{array}{c}\text { Selection of } \\
\text { Reported } \\
\text { Results }\end{array}$ & \\
\hline 1 & $\begin{array}{c}\text { Andrew IP et al., } \\
2020 \text { [18] }\end{array}$ & Moderate & Moderate & Low & Low & Low & Low & Low & Moderate \\
\hline 2 & $\begin{array}{c}\text { Biran N et } \\
\text { al.,2020[44] }\end{array}$ & Moderate & Low & Low & Low & Moderate & Low & Moderate & Moderate \\
\hline 3 & $\begin{array}{l}\text { Campochiaro C } \\
\text { et al., } 2020 \text { [33] }\end{array}$ & Low & Moderate & Low & Low & Low & Low & Low & Moderate \\
\hline 4 & $\begin{array}{c}\text { Canziani LM et } \\
\text { al.,2020[36] }\end{array}$ & Low & Low & Low & Low & Low & Low & Low & Low \\
\hline 5 & $\begin{array}{c}\text { Capra R et } \\
\text { al.,2020[21] }\end{array}$ & Low & Low & Low & Low & Low & Low & Low & Low \\
\hline 6 & $\begin{array}{c}\text { Colaneri M et al., } \\
2020[39]\end{array}$ & Moderate & Moderate & Low & Low & Moderate & Low & Low & Moderate \\
\hline 7 & $\begin{array}{c}\text { De Rossi N et } \\
\text { al.,2020 [41] }\end{array}$ & Serious & Moderate & Low & Low & Serious & Low & Low & Serious \\
\hline 8 & $\begin{array}{l}\text { Gokhale Y et } \\
\text { al.,2020 [31] }\end{array}$ & Moderate & Low & Low & Low & Low & Low & Low & Moderate \\
\hline 9 & $\begin{array}{c}\text { Guaraldi G et } \\
\text { al.,2020[28] }\end{array}$ & Moderate & Moderate & Low & Low & Low & Low & Low & Moderate \\
\hline 10 & $\begin{array}{c}\text { Kewan T et al., } \\
2020[30]\end{array}$ & Moderate & Moderate & Low & Low & Low & Low & Low & Moderate \\
\hline 11 & $\begin{array}{c}\text { Klopfenstein T et } \\
\text { al.,2020[25] }\end{array}$ & Low & Low & Low & Low & Low & Low & Low & Low \\
\hline
\end{tabular}




\begin{tabular}{|c|c|c|c|c|c|c|c|c|c|}
\hline 12 & $\begin{array}{l}\text { Martínez-Sanz J } \\
\text { et al.,2020 [23] }\end{array}$ & Low & Low & Low & Low & Low & Low & Moderate & Moderate \\
\hline 13 & $\begin{array}{l}\text { Mikulska M et } \\
\text { al.,2020 [29] }\end{array}$ & Low & Low & Low & Low & Low & Low & Low & Low \\
\hline 14 & $\begin{array}{l}\text { Moreno-García E } \\
\text { et al.,2020 [22] }\end{array}$ & Moderate & Low & Low & Low & Low & Low & Low & Moderate \\
\hline 15 & $\begin{array}{l}\text { Moreno-Pérez O } \\
\text { et al.,2020 [42] }\end{array}$ & Low & Low & Low & Low & Low & Moderate & Low & Moderate \\
\hline 16 & $\begin{array}{lll}\text { Pettit NN } & \text { et } \\
\text { al.,2020 [37] } & \end{array}$ & Moderate & Low & Low & Low & Low & Low & Low & Moderate \\
\hline 17 & $\begin{array}{l}\text { Quartuccio L et } \\
\text { al.,2020[38] }\end{array}$ & Moderate & Serious & Low & Low & Moderate & Low & Serious & Serious \\
\hline 18 & $\begin{array}{l}\text { Ramaswamy M } \\
\text { et al.,2020 [43] }\end{array}$ & Moderate & Moderate & Low & Low & Moderate & Low & Low & Moderate \\
\hline 19 & $\begin{array}{l}\text { Rojas-Marte G et } \\
\text { al.,2020 [34] }\end{array}$ & Serious & Moderate & Moderate & Moderate & Low & Low & Low & Serious \\
\hline 20 & $\begin{array}{ll}\text { Rossi B B } & \text { et } \\
\text { al.,2020[19] } & \end{array}$ & Moderate & Moderate & Low & Low & Low & Low & Low & Moderate \\
\hline 21 & $\begin{array}{l}\text { Roumier M et } \\
\text { al.,2020 [24] }\end{array}$ & Moderate & Serious & Low & Low & Low & Low & Low & Serious \\
\hline 22 & $\begin{array}{l}\text { Somers EC et al., } \\
2020[35]\end{array}$ & Low & Low & Moderate & Low & Moderate & Low & Low & Moderate \\
\hline 23 & $\begin{array}{l}\text { Wadud } \mathrm{N} \text { et } \\
\text { al.,2020 [40] }\end{array}$ & Low & Low & Moderate & Low & Low & Low & Low & Moderate \\
\hline 24 & $\begin{array}{l}\text { Zheng KL et } \\
\text { al.,2020[20] }\end{array}$ & Low & Low & Low & Low & Moderate & Low & Low & Moderate \\
\hline
\end{tabular}

1 Assessment options for each signalling question : Yes, Probably, Yes, Probably No, No, No Information.

2 Domain level RoB assessment options: Low, Moderate, Serious, Critical, No information.

3 Overall assessment (by outcome): Low, Moderate, Serious, Critical. 


\begin{tabular}{|c|c|c|c|}
\hline Sl. No & Study & $\begin{array}{c}\text { Overall RoB } \\
\text { Judgements }\end{array}$ & Comments \\
\hline 1 & Andrew IP et al., 2020 [18] & Moderate & 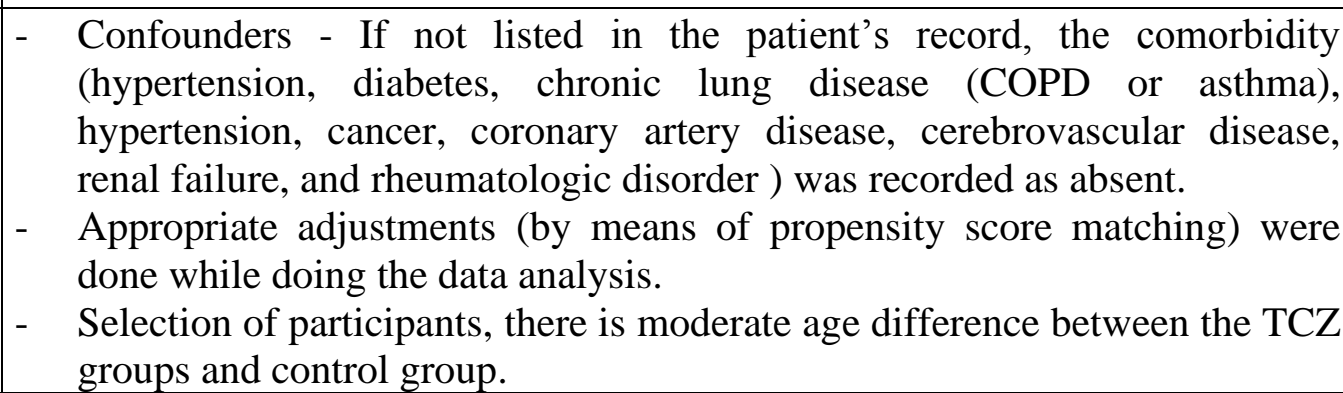 \\
\hline 2 & Biran N et al.,2020[44] & Moderate & $\begin{array}{l}\text { - Possibility of indication bias } \\
\text { - Possibility of sampling bias since we obtained data from a convenience } \\
\text { sample in attempts to do a rapid investigation during a pandemic } \\
\text { misclassifications of data was possible because the data was manually } \\
\text { extracted structured and unstructured electronic health records. }\end{array}$ \\
\hline 3 & Campochiaro C et al., 2020 [33] & Moderate & $\begin{array}{l}\text { - The control and TCZ treatment were given at different frames. Briefly, } \\
\text { patients admitted between March 13th and March 19th, } 2020 \text { were treated } \\
\text { with tocilizumab. While, the patients admitted to hospital outside the time } \\
\text { frame ( March 13th and March 19th, 2020) and who retrospectively } \\
\text { fulfilled eligibility criteria for tocilizumab treatment were used as a } \\
\text { comparison group. }\end{array}$ \\
\hline 4 & Canziani LM et al.,2020[36] & Low & $\begin{array}{l}\text { - Confounder - Difference in onset of symptoms between the treatement and } \\
\text { control group. }\end{array}$ \\
\hline 5 & Capra R et al.,2020[21] & Low & $\begin{array}{l}\text { - Subject allocation was done appropriately considering the all baseline } \\
\text { details and comorbidities. }\end{array}$ \\
\hline 6 & Colaneri M et al., 2020 [39] & Moderate & $\begin{array}{l}\text { - Confounding influence of steroid therapy on the anti-inflammatory effects } \\
\text { of tocilizumab is to be considered. } \\
\text { - Missing data is one of the main concern at day- } 7 \text {. } \\
\text { - Propensity score matching might be useful in reducing the bias since it } \\
\text { mimics randomization. }\end{array}$ \\
\hline 7 & De Rossi N et al.,2020 [41] & Moderate & $\begin{array}{l}\text { - The control and TCZ treatment were given at different frames. Briefly, } \\
\text { patients admitted between } 26^{\text {th }} \text { February } 2020 \text { to } 13^{\text {th }} \text { March } 2020\end{array}$ \\
\hline
\end{tabular}




\begin{tabular}{|c|c|c|c|}
\hline & & & $\begin{array}{l}\text { underwent a standard therapy (hydroxychloroquine } 400 \mathrm{mg} \text { daily,lopinavir } \\
800 \mathrm{mg} \text { daily plus ritonavir } 200 \mathrm{mg} \text { per day). Patients admitted after } 13^{\text {th }} \\
\text { March } 2020 \text { received off-label a single low dose administration of } \\
\text { tocilizumab in addition to standard therapy. } \\
\text { - Confounders : the patients treated with standard care were older and with } \\
\text { higher prevalence of comorbidities compared to patients treated with } \\
\text { tocilizumab. } \\
\text { - Control group including patients treated with tocilizumab during the late } \\
\text { stage of respiratory failure is missing. }\end{array}$ \\
\hline 8 & Gokhale Y et al.,2020 [31] & Moderate & - Confounders : Tocilizumab group had younger patients than control group \\
\hline 9 & Guaraldi G et al.,2020[28] & Moderate & $\begin{array}{l}\text { - Confounders : Tocilizumab group had younger patients than control group. } \\
\text { - In the tocilizumab group, there were two patients with cancer and two } \\
\text { patients with renal insufficiency, and in the standard of care group, there } \\
\text { were eight patients with cancer and seven with chronic renal insufficiency. } \\
\text { - The study was also open label, so that staff involved knew which patients } \\
\text { were receiving tocilizumab. } \\
\text { - The patients who received tocilizumab + standard of care treatment were } \\
\text { mainly selected based on the availability of the drug and they were more } \\
\text { compromised patients with lower PaO2/FiO2 ratios and higher SOFA } \\
\text { scores compared with those treated with standard of care alone. However, } \\
\text { these differences were balanced through adjusting the SOFA and Charlson } \\
\text { Comorbidity Index. }\end{array}$ \\
\hline 10 & Kewan T et al., 2020 [30] & Moderate & $\begin{array}{l}\text { - Confounders: Tocilizumab group had younger patients than control group. } \\
\text { - Confounders: Tocilizumab group had more comorbidities than control } \\
\text { group. }\end{array}$ \\
\hline 11 & Klopfenstein T et al.,2020[25] & Low & $\begin{array}{l}\text { - Confounders : Control group had younger patients than Tocilizumab group. } \\
\text { However not statistically significant. }\end{array}$ \\
\hline 12 & Martínez-Sanz J et al.,2020 [23] & Moderate & - Use of CRP instead of IL-6 limited the scope of the results. \\
\hline 13 & Mikulska M et al.,2020 [29] & Low & $\begin{array}{l}\text { - The inclusion of consecutive patients using the same SOC but not treated } \\
\text { with tocilizumab or methylprednisolone, and adjustment for the outcome- } \\
\text { associated variables, allowed to note the improvement in patient outcomes. } \\
\text { - The adjustment for the differences between patient groups through }\end{array}$ \\
\hline
\end{tabular}




\begin{tabular}{|c|c|c|c|}
\hline & & & $\begin{array}{l}\text { propensity score and conservative approach with the use of landmark } \\
\text { analysis were directly at minimizing the risk associated with an absence of } \\
\text { randomization. }\end{array}$ \\
\hline 14 & Moreno-García E et al.,2020 [ 22] & Moderate & $\begin{array}{l}\text { - } 50.6 \% \text { of Toclizumab group subjects have received Steroid prior ICU } \\
\text { admission, however it was } 27.7 \% \text { in control group. }\end{array}$ \\
\hline 15 & Moreno-Pérez O et al.,2020 [42] & Moderate & $\begin{array}{l}\text { - Misclassifications of data was possible because the data was manually } \\
\text { extracted structured and unstructured electronic health records. }\end{array}$ \\
\hline 16 & Pettit NN et al.,2020 [37] & Moderate & $\begin{array}{l}\text { - Confounding influence: differences in baseline characteristics and length of } \\
\text { stay. } \\
\text { - Possibility of selection and allocation bias. However, to avoid the bias } \\
\text { clinical score matching such as SOFA or APACHE II was performed. }\end{array}$ \\
\hline 17 & Quartuccio L et al.,2020[38] & Serious & $\begin{array}{l}\text { - The baseline values (data) for some of the subjects was not available since } \\
\text { these patients were transferred from other hospitals due to emergency. } \\
\text { - About } 50 \% \text { of the TCZ group were admitted to the ICU within } 24 \mathrm{~h} \text { from } \\
\text { admission, thus they already presented a more serious disease at the time of } \\
\text { admission. } \\
\text { - The viral load measurement was not available, while viral clearance was } \\
\text { finally assessed by repeating swab test in almost all } \\
\text { the patients. }\end{array}$ \\
\hline 18 & Ramaswamy M et al.,2020 [43] & Moderate & $\begin{array}{l}\text { - The patients allocated to TCZ group are slightly older and sicker than } \\
\text { control group. } \\
\text { - This study has possible inclusion or selection bias. } \\
\text { - } \quad \text { There was missing laboratory values for some of the patinets. }\end{array}$ \\
\hline 19 & Rojas-Marte G et al.,2020 [34] & Serious & $\begin{array}{l}\text { - The control and treatment groups were not matched. } \\
\text { - Confounding: More patients in the TCZ group were of male sex, reported } \\
\text { more fever, cough and shortness of breath and with lower oxygen } \\
\text { saturation }\end{array}$ \\
\hline 20 & Rossi B et al.,2020[19] & Moderate & $\begin{array}{l}\text { - The control and treatment groups were not matched. The patients in the } \\
\text { SOC group were older than TCZ treated group. However, multivariate Cox } \\
\text { proportional hazard model was applied to remove the potential biasing } \\
\text { effect of these unmatched variables on the primary results. } \\
\text { - An additional control group, including patients treated with tocilizumab } \\
\text { during the late stage of respiratory failure is missing. } \\
\text { - Confounding factors: The patient's inclusion strategy applied does not }\end{array}$ \\
\hline
\end{tabular}




\begin{tabular}{|c|l|l|l|}
\hline & & & $\begin{array}{l}\text { allow to definitely ruleout the potential impact of unmeasured and } \\
\text { unconscious confounding factors on the results, as for Example the } \\
\text { acquired clinical experience of managing the disease. }\end{array}$ \\
\hline 21 & Roumier M et al.,2020 [24] & Serious & $\begin{array}{l}\text { Confounding factors: The patients allocated to control group are slightly } \\
\text { older and more Cardiovascular and cerebrovascular comorbidities than } \\
\text { TCZ group. }\end{array}$ \\
\hline 22 & Somers EC et al., 2020 [35] & Moderate & $\begin{array}{l}\text { For patients transferred from other hospitals due to emergency, the baseline } \\
\text { data on initial period of care and status of toclizumab administration prior } \\
\text { to transfer is not consistently available. } \\
\text { Tocilizumab administration protocol was not standardized. }\end{array}$ \\
\hline 23 & Wadud N et al.,2020 [40] & Low & $-\quad$ Unclear acquisition of control. causes of death are not clear. \\
\hline 24 & Zheng KL et al.,2020 [20] & Moderate & - Missing Viral load data. \\
\hline
\end{tabular}

1

\section{Reference :}

3 Sterne Jonathan AC, Hernán Miguel A, Reeves Barnaby C, Savović Jelena, Berkman Nancy D, Viswanathan Meera et al. ROBINS-I:

4 a tool for assessing risk of bias in non-randomised studies of interventions BMJ 2016; 355 :i4919. https://doi.org/10.1136/bmj.i4919 